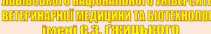
trific messenger at 1 w lliciene and Biotechnologites (4) $10 \sqrt{10191}$

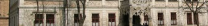
(1)

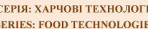
Том 21 № 91

Науковий вісник Дьвівського національного університету ветеринарної медицини та біотехнологій імені С.3. Гжицького. Серія: Харчові технології

Scientific Messenger of Lviv National University of Veterinary Medicine and Biotechnologies.

Series: Food Technologies

ISSN 2519-268X print

https://nvlvet.com.ua/index.php/food

doi: 10.32718/nvlvet-f9102

UDC 664.663.9

\title{
Investigation of lipids of flax seed meal and the prospect of using it in meat dishes
}

\author{
O.P. Izhevska \\ Lviv State University of Physical Culture, Lviv, Ukraine
}

Article info

Received 09.01.2019

Received in revised form 11.02 .2019

Accepted 12.02.2019

Lviv State University of Physical Culture, Kostyushka Str., 11, Lviv, 79007, Ukraine.

Tel.: +38-096-281-76-95

E-mail: grb@ldufk.edu.ua

Izhevska, O.P. (2019). Investigation of lipids of flax seed meal and the prospect of using it in meat dishes. Scientific Messenger of Lviv National University of Veterinary Medicine and Biotechnologies. Series: Food Technologies, 21(91), 9-13. doi: 10.32718/nvlvet-f9102

The possibility of using a plant supplement is considered in materials of the article, namely, the seed meal of flax in the recipe for meat semi-finished products "Mazurki-Volynsky" to enrich these products with physiological-functional ingredients. Flax seeds is a valuable source of polyunsaturated fatty acids. It is rich in protein substances, balanced by the amino acid, contains insoluble and water-soluble edible fibers and phenolic compounds, in particular lignans, which have antioxidant properties. In this work, a flax seeds (FS) was obtained by using the method of "cold pressing" produced by NV "Zhytomyrbioprodukt" LLC. Fatty acid composition of lipids was determined according to GOST 30418-96. The method is based on the conversion of triglycerides of fatty acid to methyl (ethyl) esters of fatty acids and on their gas chromatic analysis. The purpose of our research was to determine from the technological point of view the expediency of introducing the flax seeds into the recipes of meat semi-finished products to enrich their health-improving ingredients. For this purpose, in studies, a complete replacement of wheat flour and a partial replacement of fat material by the use of flax seed is proposed. Thus, compared to the control, the amount of meat raw material does not change, and the change occurs only at the expense of the filler of meal. The article presents a comparative estimation of the chemical composition of the flax seeds and wheat flour, the effect of flax on the change of the lipid composition of meat semi-finished products in case of its inclusion in the recipe of products. The fatty acid composition of sorbitol lipids was investigated in comparison with the fatty acid composition of the wheat flour I flavors. It is noted that the inclusion into the recipe of meat semifinished flax seed meal in the case of replacing wheat flour and part of the fat, enriches them with such physiological-functional ingredients as proteins with a complete amino acid composition, polyunsaturated fatty acids, edible fibers, a significant part of which are water-soluble, vitamins, micro- and macro elements, lignans. The calculation method found that the amount of protein in the experimental sample, as compared with the sample, which included wheat flour, increased by 3.69\% due to the increase of protein contained in FS. Adding FS changes the qualitative composition of the lipid in exploratory samples. The calculation method found that the content of polyunsaturated fatty acids (PUFAs) increased by $12 \%$ compared with control. It should be noted that the ability of these fatty acids to oxidation, with the formation of peroxides, will affect the structural and mechanical properties of semi-finished products, which should affect the process of preparation and quality of finished products. This requires further research.

Key words: flax seed, wheat flour, edible fibers, fatty acid composition of lipids, chemical composition of raw materials.

\section{Дослідження ліпідів шроту насіння льону та перспектива використання його у м'ясних стравах}

\author{
О.П. Іжевська
}

Львівський державний університет фізичної культури, м. Львів, Украӥна

В матеріалах статті розглянуто можливість використання рослинної добавки, а саме шроту насіння льону в реиептурі м'ясних напівфабрикатів “Мазурки по-волинськи” для збагачення циих виробів фізіологічно-функціональними інгредієнтами. Шрот насіння льону є цінним джерелом поліненасичених жсиних кислот. Він багатий білковими речовинами, щуо збалансовані за аміноки- 
слотним складом, містить нерозчинні та розчинні у воді харчові волокна та фенольні сполуки, зокрема лігнани, які володіють антиоксидантними властивостями. У роботі використовували шрот насіння льону (ШНЛ), одержаний методом “холодного пресування” виробництва НВ ТОВ “Житомирбіопродукт”. Жирнокислотний склад ліпідів визначали за ГОСТ З0418-96. Метод трунтується на перетворенні триглічеридів жирних кислот в метилові (етилові) ефіри жирних кислот і їх газохроматичному аналізі. Метою наших досліджень було визначення доиільності внесення шроту насіння льону у рецептуру м'ясних напівфабрикатів для збагачення їх оздоровчими інгредієнтами. Таким чином у дослідженнях пропонується повна заміна пшеничного борошна та часткова заміна жиру-сирцю шротом насіння льону. Порівняно з контролем кількість м'ясної сировини не змінюється, а зміна відбувається лише за рахунок наповнювача шроту. У статті подано порівняльну оцінку хімічного складу шроту насіння льону та пшеничного борошна, вплив шроту на зміну ліпідного складу м'ясних напівфабрикатів у разі включення його до рецептури виробів. Досліджено жирнокислотний склад ліпідів шроту порівняно з жирнокислотним складом ліпідів пшеничного борошна I сорту. Розрахунковим методом встановлено, ше кількість білка у дослідному зразку порівняно зі зразком, куди входило пшеничне борошно, збільшилась на 3,69\% за рахунок збільшення білка, ще міститься в ШНЛ. Додання ШНЛ змінює якісний склад ліпідів дослідного зразка. Розрахунковим методом встановлено, щуо вміст поліненасичених жсиних кислот (ПНЖК) збільшується на $12 \%$ порівняно з контролем. Варто зазначити, щзо здатність иих жирних кислот до окиснення з утворенням пероксидів зумовлюватиме вплив на структурномеханічні властивості напівфабрикатів, щчо має позначатись на перебігу технологічного процесу приготування та якості готових виробів. Це потребує подальших досліджень.

Ключові слова: шрот насіння льону, борошно пиеничне, харчові волокна, жирнокислотний склад ліпідів, хімічний склад сировини.

\section{Вступ}

Заклади ресторанного господарства надають споживачам комплекс різноманітних послуг, пріоритетною серед яких залишається надання послуги харчування. Харчування є найважливішим фактором, що задовольняє фізіологічні потреби організму людини в енергії та харчових речовинах, які здатні посилювати опір організму людини несприятливому впливу навколишнього середовища та інфекційним і неінфекційним захворюванням.

Актуальність теми: За останні роки якість та структура харчування значно погіршилася. Дефіцитними у харчових раціонах стали повноцінні білки, ненасичені жирні кислоти, життєво необхідні вітаміни, макро- та мікроелементи, харчові волокна (Peresichnyi et al., 2008; Smoliar, 2011).

Як показує практика, сприятливим аспектом для розширення асортименту та підвищення конкурентоздатності продуктів харчування є впровадження прогресивних технологій, модернізованого устаткування, раціонального використання сировинних ресурсів. Зокрема збагатити харчові раціони можна за рахунок нетрадиційної рослинної сировини, яку в достатній кількості можуть запропонувати вітчизняні виробники.

Важливу роль у житті людини відіграють ліпіди, а саме їхні складові - ненасичені жирні кислоти, які входять до складу жирових клітин і виконують функцію життєво важливих процесів організму, зокрема беруть участь у жировому обміні. Їх нестача призводить до порушень функції центральної нервової системи, патології шкіри, нирок, зору, послаблення імунобіологічних механізмів.

Середня добова потреба організму в харчових ліпідах складає 80-100 г, з них 30\% тваринного походження. Для забезпечення нормального функціонування організму необхідно, щоб у складі добового раціону ліпідів співвідношення насичених (НЖК), поліненасичених (ПНЖК сичених жирних кислот (МНЖК) було 33,5 : 30,0 : 3,0 $: 33,5$.

На ПНЖК багаті рослинні ліпіди. Вони мають здатність знижувати рівень холестерину в крові і тим запобігають розвитку атеросклерозу. Основним джерелом ПНЖК є рослинні олії та вторинні продукти їх виробництва - макуха, шрот (Titov, 2001; Shimanskaja \& Osejko, 2012).

Нині в зв'язку з теперішніми вимогами до харчування науковці та виробничники все більше уваги приділяють використанню білково-олійних культур і продуктам їхньої переробки як джерелам повноцінного білка, ненасичених жирних кислот, вітамінів, низки макро- та мікроелементів та інших біологічноактивних речовин (Shherbakov, 1991; Nikitchin, 1996).

Перспективним видом сировини, що містить фізіологічно-функціональні інгредієнти, є насіння льону та продукти його переробки. В останнє десятиліття у розвинених країнах світу спостерігається їх активне споживання.

Особлива увага використання насіння льону у хлібобулочних виробах приділяється у країнах Свропи, в Америці, Японії та інших (Kelvin et al., 2006; Lipina \& Canji, 2009).

Так, у Німеччині щорічно використовують понад 60000 т насіння льону в харчовій промисловості. Це 1 кг на людину в рік. Значна частина його додається при виробництві хліба.

Наприклад, в США та Канаді на рівні Міністерств охорони здоров'я сформовано рекомендації щодо обов'язкового щоденного вживання насіння льону в їжу (Inglett et al., 2013; Hera et al., 2014). В США, Канаді насіння льону та борошно 3 нього входять до складу рецептури понад 100 видів хлібобулочних виробів. В Канаді, де смертність від раку займає перше місце, прийнята спеціальна Національна програма щодо льону, яка рекомендує включати до 12\% НЛ у хлібобулочні вироби.

Цінність насіння льону та продуктів його переробки обумовлена наявністю в його складі поліненасичених жирних кислот, лігнанів, харчових волокон, білків $з$ повноцінним амінокислотним складом, макро- та мікроелементів і вітамінів.

За даними літературних джерел, в насінні льону міститься, мг/100 г кальцій (250-260), магній (384400), натрій (29-31), калій (797-829), фосфор (629655). Мікроелементи представлені (мг/100 г) залізом 
$(5,62-5,84)$, цинком $(4,25-4,43)$, марганцем $(2,43-$ 2,53), міддю (1,20-1,24), селеном $(25,4)$ (Los', 2006).

Вміст калію в 2,3-2,6 разу вищий, ніж у пшениці. Як джерело селену насіння льону сприяє очищенню організму від солей важких металів, поліпшує мозкову діяльність організму. Окрім того, воно здатне концентрувати кремній, що має суттєве значення у нинішній екологічній ситуації (Koval' \& Pashhenko, 2001).

Цінність насіння також обумовлена наявністю водорозчинних вітамінів та токоферолу. За даними (Zubcov et al., 2002), в НЛ міститься (мг/100 г) тіаміну $\left(\mathrm{B}_{1}\right)-1,64$; рибофлавіну $\left(\mathrm{B}_{2}\right)-0,16$; пантотенової кислоти $\left(\mathrm{B}_{3}\right)-0,98$; піридоксину $\left(\mathrm{B}_{6}\right)-0,43$; фолієвої кислоти $\left(\mathrm{B}_{9}\right)-87$ мкг; аскорбінової кислоти $(\mathrm{C})-$ 0,60 ; токоферолу (Е) - 0,31. У НЛ міститься значна кількість рутину, що $є$ природним антиоксидантом. Вітамін Е разом із флавоноїдами і вітаміном С входить до антиоксидантної системи організму.

Насіння льону є джерелом рослинних фітоестрогенів, фенольних сполук, зокрема лігнанів (піноресинол і ларисиресинол), що мають високі антиоксидантні властивості (Barthet et al., 2014). У лляному насінні набагато більше лігнанів, ніж в інших рослинних продуктах (Barthet et al., 2014).

Ліпіди насіння льону характеризуються вмістом насичених жирних кислот і високим вмістом ненасичених жирних кислот (олеїнової - 17-22\%, лінолевої - 15-20\%, $\alpha$-ліноленової - до 55\%), від суми жирних кислот. Насичені жирні кислоти складають 9-12\% від загальної кількості жирних кислот. Індекс ненасиченості (U/S)ліпідів насіння - 7,3-7,8 (Shimanskaja \& Osejko, 2012).

Співвідношення цих кислот є важливим для нормального розвитку людського організму. Дослідження показують, що високий вміст в дієті лінолевої кислоти сприяє посиленню в'язкості крові, викликає звуження судин, тимчасом як ліноленова жирна кислота має судинорозширювальні властивості та антистресову і антиаритмічну дію.

Насіння льону характеризується великим вмістом ненасичених жирних кислот. При оцінці фізіологічної цінності цих кислот має значення вміст і співвідношення $\omega_{3}$ і $\omega_{6}$ поліненасичених жирних кислот. Оптимальне співвідношення між $\omega_{3}$ i $\omega_{6}$ жирними кислотами не встановлено. Ця проблема активно обговорюється у науковій літературі. На думку різних авторів, це співвідношення має бути в межах 1:4 - 1:10. Співвідношення між насиченими (НЖК), поліненасиченими (ПНЖК) і мононенасиченими (МНЖК) жирними кислотами має бути таке: НЖК : ПНЖК : МНЖК = 33,5 : 30,0: 3,0 : 33,5. За даними (Shimanskaja \& Osejko, 2012) в лляній олії співвідношення $\omega_{3} \mathrm{i}$ $\omega_{6}$ жирних кислот складає 1:0,25, тимчасом як у олії пшениці 1:8,5. Тобто олія льону здатна доповнити олію пшениці поліненасиченими жирними кислотами i насамперед $\omega_{3}$ жирною кислотою.

Дослідженнями, проведеними О. Юрченко, на модельній системі встановлено, що нерозчинні харчові волокна насіння льону здатні “згасити” $72 \%$ радикалів, антиоксидантна активність насіння льону складає $52 \%$, а лляного шроту - 63\% (Iurchenko, 2011).
Крім цього, лляний шрот є джерелом більшості вітамінів, таких як $\mathrm{B}_{1}, \mathrm{~B}_{2}, \mathrm{~B}_{6}$, ніацину (РP), пантотенової $\left(\mathrm{B}_{3}\right)$ та фолієвої кислоти $\left(\mathrm{B}_{9}\right)$, біотину $\left(\mathrm{B}_{7}\right)$, токоферолу (вітамін Е). Особливе значення має вміст тіаміну $\left(\mathrm{B}_{1}\right)$. Цей продукт $є$ природним джерелом селену. Дослідами, проведеними вченими університету штату Південна Дакота (США), було встановлено, що вміст селену в лляному шроті коливається від 0,13 до 3,06 мг/кг або в середньому понад 1 мг на 1 кг продукту (Tolkachev \& Zhuchenko, 2000).

Значної актуальності набуває можливість використання нетрадиційної сировини у складі м'ясних продуктів. Вітчизняними і зарубіжними вченими доведено доцільність створення комбінованих м'ясних продуктів, що включають рослинні складові та мають високі споживчі властивості.

Сучасна тенденція в галузі вдосконалювання структури харчування спрямована на створення асортименту продуктів, збагачених біологічно активними речовинами шляхом використання рослинних добавок, які все ширше застосують в різних харчових продукTax.

Метою наших досліджень було визначення 3 технологічної точки зору доцільності внесення шроту насіння льону в рецептуру м'ясних напівфабрикатів для збагачення їх оздоровчими інгредієнтами. 3 цією метою у дослідженнях пропонується повна заміна пшеничного борошна та часткова заміна жиру-сирцю шротом насіння льону. Таким чином, порівняно 3 контролем кількість м'ясної сировини не змінюється, а зміна відбувається лише за рахунок наповнювача шроту. Завданням даного дослідження було визначення ступеня збагачення м'ясних січених напівфабрикатів функціональними інгредієнтами.

\section{Матеріал і методи досліджень}

У дослідженнях використовували шрот насіння льону (ШНЛ), одержаний методом холодного пресування виробництва НВ ТОВ “Житомирбіопродукт" 3 певним хімічним складом, що наведено у табл. 1 (Drobot et al., 2016).

\section{Таблиця 1}

Хімічний склад шроту насіння льону та пшеничного борошна першого сорту, \%

\begin{tabular}{lcc}
\hline \multicolumn{1}{c}{ Складові } & Борошно & Шрот \\
\hline Білки, \% & $11,6 \pm 0,3$ & $32,6 \pm 0,3$ \\
Вуглеводи загальні, \% & $73,3 \pm 0,5$ & $40,4 \pm 0,5$ \\
в т.ч. моно- та дисахариди, \% & $1,8 \pm 0,05$ & $2,5 \pm 0,05$ \\
крохмаль, \% & $68,0 \pm 0,5$ & - \\
харчові волокна, \% & $3,5 \pm 0,3$ & $37,6 \pm 0,5$ \\
в т.ч. пентозани & $2,4 \pm 0,1$ & $8,6 \pm 0,1$ \\
Жири, \% & $1,35 \pm 0,1$ & $10,5 \pm 0,1$ \\
Зольність, \% & $0,73 \pm 0,05$ & $5,6 \pm 0,05$ \\
Волога, \% & $13,0 \pm 0,03$ & $11,2 \pm 0,03$ \\
\hline
\end{tabular}

Результатами досліджень (Drobot et al., 2016), встановлено, що шрот насіння льону за хімічним складом суттєво відрізняється від пшеничного борошна - містить 37,6\% харчових волокон, понад 10\% 
ліпідів та 32,6\% білків, значна частина яких водорозчинна. Шрот насіння льону не містить крохмалю, вуглеводи шроту представлені в основному харчовими волокнами. Розчинних волокон (слизів) в ньому в 3,6 разу більше, ніж в пшеничному борошні.

Лляний шрот є вторинним продуктом, який одержують у технології лляної олії і в процесі виробництва можливі зміни в складі жирних кислот шроту порівняно з їх складом в насінні льону.

Для обгрунтування доцільності повної заміни пшеничного борошна та часткової заміни сала шпику шротом насіння льону досліджували жирнокислотний склад ліпідів шроту порівняно 3 жирнокислотним складом ліпідів пшеничного борошна I сорту.

Жирнокислотний склад ліпідів визначали за ГОСТ 30418-96. Метод грунтується на перетворенні тригліцеридів жирних кислот в метилові (етилові) ефіри жирних кислот і їх газохроматичному аналізі.

У дослідженнях за контроль було взято “Мазурки по-волинськи" (Збірник рецептур національних страв, рец. 1.304) з таким рецептурним складом на 100 г напівфабрикату: яловичина 66 г, жир-сирець 10 г, яйця 4 г, вода 10 г, борошно пшеничне 10 г. Недолі- ком зазначеного продукту є знижений вміст білків, поліненасичених жирних кислот та підвищений вміст вуглеводів через наявність у рецептурі пшеничного борошна.

\section{Результати та їх обговорення}

Розрахунковим методом можна встановити, що кількість білка у дослідному зразку порівняно зі зразком, куди входило пшеничне борошно, збільшилась на 3,69\% за рахунок збільшення білка, що міститься в ШНЛ.

Проведеними дослідженнями встановлено (табл. 2), що у ШНЛ НВ ТОВ “Житомирбіопродукт” міститься втричі менше насичених жирних кислот, на $21 \%$ менше - мононенасичених і на 49,8\% більше поліненасичених жирних кислот, порівняно з пшеничним борошном. Співвідношення НЖК : ПНЖК : МНЖК складає 8,3 : 74,3 : 16,0, а ПНЖК $6-1: 0,35$, тимчасом як у пшеничному борошні 26,7 : 49,6 : 20,3 і $1: 6,8$. Тобто шрот є джерелом поповнення м'ясних січених напівфабрикатів поліненасиченими жирними кислотами.

\section{Таблиця 2}

Жирнокислотний склад ліпідів, \% $(\mathrm{n}=3, \mathrm{P} \leq 0,95)$

\begin{tabular}{|c|c|c|}
\hline Назва жирних кислот & Шрот льону & Борошно пшениці \\
\hline Насичені жирні кислоти & 8,297 & 26,747 \\
\hline С6:0 (Капронова) & 0,006576 & 1,393 \\
\hline C10:0 (Каприлова) (октанова) & 0,01988 & 0,156 \\
\hline C12:0 (Лауринова) & 0,01542 & 8,706 \\
\hline C14:0 (Міристинова) (тетрадеканова кислота) & 0,06745 & 0,864 (сліди) \\
\hline С15:0 (Пентадеканова) (пентадеиилова) & 0,02889 & 1,201 \\
\hline Пальмітинова (Гексадеканова кислота) & 7,420 & 12,81 \\
\hline Гептадеканова (Маргаринова) & 0,009922 & 0,697 \\
\hline Стеаринова (Октадеканова кислота) & 0,2461 & 0,920 \\
\hline Арахінова (Эйкозанова) & 0,1367 & - \\
\hline Бегенова & 0,1112 & - \\
\hline Трикозанова & 0,2448 & - \\
\hline Мононенасичені жирні кислоти & 16,015 & 20,253 \\
\hline Пальмітолеїнова & 0,04624 & 0,545 \\
\hline Олеїнова (Омега-9) & 8,918 & 15,025 \\
\hline Міристолеїнова & 0,002391 & 1,933 \\
\hline Елаідинова (Омега-9) & 0,4640 & - \\
\hline Ліноелаїдинова & 6,071 & 2,010 \\
\hline Нервонова (селахолева) (Омега-9) & 0,3869 & - \\
\hline Гондоінова & 0,1266 & - \\
\hline Ерукова & - & 0,739 \\
\hline Поліненасичені жирні кислоти & 74,34 & 49,618 \\
\hline Лінолева (Омега-б) & 5,072 & 39,200 \\
\hline Альфа-ліноленова (Омега-3) & 54,81 & 6,318 \\
\hline Гамма-ліноленова (Омега-6) & 14,10 & - \\
\hline Ейкозапентаенова (Омега-3) & 0,06308 & - \\
\hline Докозагексаенова (Омега-3) & 0,01669 & - \\
\hline Докозадієнова (Омега-б) & 0,05157 & 0,357 \\
\hline Ейкозадієнова (Омега-6) & 0,1066 & 3,540 \\
\hline Дигомо- $\gamma$-линоленова кислота & 0,0554 & 0,203 \\
\hline Арахідонова (Омега-6) & 0,0650 & - \\
\hline Всього & 98,652 & 97,610 \\
\hline Не ідентифікованих & 1,348 & 2,39 \\
\hline
\end{tabular}

У складі жирів шроту 74,3\% поліненасичених жирних кислот, серед яких переважає вміст $\omega_{3}$ i $\omega_{6}$ жирні кислоти. Додання ШНЛ змінює якісний склад ліпідів дослідного зразка. Розрахунковим методом встановлено, що вміст поліненасичених жирних кислот (ПНЖК) збільшується на $12 \%$ порівняно з контролем. 


\section{Висновки}

Отже, таку нетрадиційну сировину, як шрот насіння льону доцільно додавати до рецептури м'ясних січених напівфабрикатів з метою впровадження продуктів збалансованого жирнокислотного складу.

Аналізуючи жирнокислотний склад ліпідів ШНЛ, можна передбачати, що значно більший, ніж в борошні, вміст в ШНЛ поліненасичених жирних кислот, які за своєю природою мають високу реакційну здатність (взаємодіючи з різними хімічними групами білків, а також адсорбуючись на поверхні білка м'яса) впливатиме на властивості м'ясних січених напівфабрикатів.

Варто зазначити, що здатність цих жирних кислот до окислення, з утворенням пероксидів, зумовлюватиме вплив на структурно-механічні властивості напівфабрикатів, що має позначатись на перебігу технологічного процесу приготування та якості готових виробів.

Перспективи подальших досліджень. Оскільки льонопродукти змінюють хімічний склад м'ясних напівфабрикатів, доцільно вивчити їхній вплив на перебіг мікробіологічних, біохімічних та колоїдних процесів, структурно-механічні властивості напівфабрикатів, споживчі та функціональні властивості м'ясних страв. Розроблення технологічних заходів впливу на інтенсивність та регулювання технологічного процесу, поліпшити якості виробів з цією сировиною потребує подальших досліджень.

Впровадження у виробництво м'ясних січених напівфабрикатів зі шротом насіння льону в закладах ресторанного господарства потребує наукового обгрунтування та удосконалення технології у разі його використання.

\section{References}

Barthet, J.V., Klensporf-Pawlik, D., \& Przybylski, R. (2014). Antioxidant activity of flax seed meal components. Journal of Plant Science, 94(3), 593-602. doi: 10.4141/cjps2013-018.

Drobot, V.I., Izhevska, O.P., Teslia, O.D., Bondarenko, Yu.V. (2016). Efektyvnist vykorystannia shrotu nasinnia lonu u khlibopekarnii promyslovosti. Prodovolchi resursy: zbirnyk naukovykh prats Instytutu prodovolchykh resursiv NAAN Ukrainy. K. NNTs "IAE", 7, 210-213 (in Ukrainian).

Hera, E., Ruiz-Paris, E., Oliete, B., \& Gomez, M. (2014). Studies of the quality of cakes made with wheat-lentil composite. LWT-Food Sci and Technol, 49(1), 48-54. doi: 10.1016/j.lwt.2012.05.009.

Inglett, G.E., Chen, D., \& Lee, S. (2013). Rheologicai properties of Barley and Flaxseed composites. Food and Nutrition Sciences, 4, 41-48. doi: 10.4236/fns.2013.41007.

Iurchenko, O.O. (2011). Nasinnia lonu ta produkty na yoho osnovi yak pryrodni antyoksydanty. Khranenye y pererabotka zerna, 4, 66-67 (in Ukrainian).

Kelvin, K.T., Goh, D.N., Christopher, E.H., \& Hemar, Y. (2006). Rheological and Light Scattering Properties of Flaxseed Polysaccharide Aqueous Solutions. Biomacromolecules, 7(11), 3098-3103. doi: 10.1021/bm060577u.

Koval', L., \& Pashhenko, V.O, (2001). O funkcional'nyh svojstvah semjan maslichnogo l'na. KhKP Ukrainy, 3, 42 (in Russian).

Lipina, E., \& Canji, V. (2009). Incorporation of ground flaxseed into bakery products and its effect on sensory and nutritional characteristics - a pilot study. Journal of Foodservice, 20(1), 52-59. doi: 10.1111/j.17480159.2008.00124.x.

Los', O.A. (2006). Razrabotka tehnologii jenterosorbentov na osnove semeni l'na i produktov ego pererabotki: dis. kand. tehn. nauk: 03.00.20 Los' Ol'ga Aleksandrovna. Odessa (in Russian).

Nikitchin, D.I. (1996). Maslichnye kul'tury. Zaporozh'e. VPK “Zaporizhzhja” (in Russian).

Peresichnyi, M.I., Kravchenko, M.F., \& Fedorova, D.V. (2008). Tekhnolohiia produktiv kharchuvannia funktsionalnoho pryznachennia. monohrafiia. K. KNTEU (in Ukrainian).

Shherbakov, V.G. (1991). Biohimija i tovarovedenie maslichnogo syr'ja. M. Agropromizdat (in Russian).

Shimanskaja, E.I., \& Osejko, N.I. (2012). Fosfolipidnye zhirovye produkty funkcional'nogo naznachenija. Harchova nauka i tehnologija, 1(18), 28-30 (in Russian).

Smoliar, V.I. (2011). Zakony ratsionalnoho kharchuvannia v suchasnii nutrytsiolohii. Problemy kharchuvannia. 1-2(24), 5-12 (in Ukrainian).

Titov, V.N. (2001). Ateroskleroz, kak patologija polienovyh zhirnyh kislot. Voprosy pitanija, 3, 48-53 (in Russian).

Tolkachev, O.N., \& Zhuchenko, A.A. (2000). Biologicheski aktivnye veshhestva l'na: ispol'zovanie v medicine i pitanii. Himiko-farmacevticheskij zhurnal, 7, 23-30 (in Russian).

Warrand, J., Michaud, P., Picton, L., Muller, G., Courtois, B., Ralainirina, R., \& Courtous, J. (2005). Structural investigations of the neutral polysaccharide of Linum usitatissimum L. seed mucilage. Int. J. Biol. Macromol. 35(34), 121-125. doi: 10.1016/j.ijbiomac.2004.12.006.

Zubcov, V.A., Lebedeva, T.I., \& Osipova, L.L. (2002). Potrebitel'skaja cennost' semjan l'na. Agrarnaja nauka, 11, 7-9 (in Russian). 